\title{
Impact of administering antibacterial agents on wild fish and blue mussels Mytilus edulis in the vicinity of fish farms
}

\author{
A. Ervik ${ }^{1}$, B. Thorsen ${ }^{2}$, V. Eriksen ${ }^{1}$, B. T. Lunestad ${ }^{3}$, O. B. Samuelsen ${ }^{4, *}$ \\ ${ }^{1}$ Institute of Marine Research, Department of Aquaculture, Strandgaten 229, N-5024 Nordnes, Bergen, Norway \\ ${ }^{2}$ Department of Microbiology and Plant Physiology, University of Bergen, Jahnebakken 5, N-5007 Bergen, Norway \\ ${ }^{3}$ Directorate of Fisheries, Department of Quality Control, Strandgaten 229, N-5002 Bergen, Norway \\ ${ }^{4}$ Department of Clinical Biology, Section of Pharmacology, School of Medicine, University of Bergen, Amauer Hansens Hus, \\ N-5021 Bergen, Norway
}

\begin{abstract}
Using high-performance liquid chromatography, residues of the quinolones oxolinic acid and flumequine have been quantified in muscle of wild fish. The fish were caught 0 or $1 \mathrm{~d}$ after terminating medication in the vicinity of 6 fish farms previously employing one of the drugs. The majority of the wild fish (74 to $100 \%$ of the catch at the different farms) contained drug residues in muscle. The mean muscle concentration varied from 0.95 to $4.89 \mu^{-1} \mathrm{~g} \mathrm{~g}^{-1}$ (ppm). Using a standard microbiological method, $60 \%$ of the examined fish were found to contain faecal material displaying antibacterial activity. The occurrence of bacteria resistant to oxolinic acid and oxytetracycline in blue mussels Mytilus edulis and in the intestinal content of fish was also examined. The level of resistant bacteria was higher in samples taken at the farm after medication than in samples collected before medication or from untreated areas.
\end{abstract}

KEY WORDS: Aquaculture - Antibacterial agents - Environment

\section{INTRODUCTION}

The increasing intensity of fish farming in Norway, especially during the last decade, has inevitably been accompanied by an increase in the occurrence of infectious diseases. This has resulted in production losses, of which bacterial infections caused by Vibrio anguillarum (classical vibriosis), V. salmonicida (cold-water vibriosis) and Aeromonas salmonicida (furunculosis) have been the most serious causes. Since effective vaccines have been available for only a limited range of pathogens, chemotherapy has been considered to be the most effective weapon against bacterial diseases. Fish suffering from bacterial infections are usually treated orally using food pellets containing the desired antibacterial agent. Since diseased fish often show a reduced feed intake, over-feeding may occur and

\footnotetext{
- Addressee for correspondence
}

excess food pellets may thus enter the surroundings. Furthermore, the bioavailability of the antibacterial agents in use in Norwegian fish farming today is relatively low, and therefore drugs enter the environment via faeces (Bjørklund \& Bylund 1991, Hustvedt et al. 1991\}. During feeding, drugs may also be released from the pellets as fragments or dissolve in the seawater (Higuera et al. 1990). Consequently, antibacterial agents reach the wild fauna. Samuelsen et al. (1992) found an elevated level of bacteria resistant to oxolinic acid (OXA) in blue mussels Mytilus edulis collected at a farm on the day medication with this drug was terminated. During and shortly after medication, wild fish, mussels and crustaceans in the vicinity of the farms also contain drug residues (Møster 1986, Bjørklund et al. 1990, Samuelsen et al. 1992). Møster (1986) found concentrations of $7 \mu \mathrm{g} \mathrm{g}^{-1}$ (ppm) of oxytetracycline (OTC) in the hepatopancreas of blue mussels collected at the farm site and detectable concentrations in mus- 
sels harvested $80 \mathrm{~m}$ from the farm. Bjørklund et al. (1990) found OTC levels ranging from 0.2 to $1.3 \mu \mathrm{g} \mathrm{g}^{-1}$ in 8 muscle samples of bleak Alburnus alburnus collected on the last day of medication at a fish farm in the Baltic sea. Samuelsen et al. (1992) found residues of OXA in saithe Pollachius virens, mackerel Scomber scombrus, ballan wrasse Labrus bergylta, haddock Melanogrammus aeglefinus, ling Molva molva, cod Gadus morhua, pollack Pollachius pollachius, flounder Platichthys flesus, salmon Salmo salar, crab Cancer pagurus and blue mussels sampled within $400 \mathrm{~m}$ of 2 farms on the day medication with this drug was terminated. The mean concentrations of all positive muscle samples were 4.38 and $0.42 \mu \mathrm{g} \mathrm{g}^{-1}$ respectively at the 2 farms and the maximum concentration found in a muscle sample was $12.51 \mu g^{-1}$ The highest concentrations (both maximum and mean) were found in saithe.

The calculated mean muscle concentrations of OXA varied considerably between the 2 farms. Therefore, to verify previous findings, wild fish were sampled in the vicinity of 6 marine salmon farms medicating with OXA or flumequine (FLU). In addition, laboratory experiments were performed to investigate the absorption and excretion of OXA in saithe since we, like Carss (1990), found saithe to be the most abundant species at the farms. To study the occurrence and spread of bacteria resistant to OXA and OTC during medication, fish intestines and blue mussels were collected both from 2 of the farm sites and from unaffected areas.

\section{MATERIALS AND METHODS}

Chemicals. OXA, OTC and FLU were obtained from Norsk Medisinaldepot A/S (Bergen, Norway). Methanol, acetonitrile, tetrahydrofuran (HPLC grade), dichloromethane, sodium hydroxide and oxalic acid dihydrate (pro analysis grade) were all from Merck (Darmstadt, Germany).

Field investigation. Sampling sites: Muscle samples from wild fish were collected at 6 marine fish farms lo- cated on the west coast of Norway in the Hordaland and Sogn og Fjordane regions during the winter of 1991-92. Microbiological studies of blue mussels and intestines were performed at 2 farms. Further specifications of the farms are given in Table 1.

Sampling: Samples were collected 2 d prior to treatment (Farm 4), the last day of medication (Farms 1 \& 2) or the first day following termination of medication (Farms 3, 4, $5 \& 6$ ). The fish were caught by gill nets placed within $50 \mathrm{~m}$ of the farm or by angling from the farm site. The fish were measured (fork length), weighed and samples of fish intestine (Farms 1 \& 4) and muscle were taken at the farm site. Blue mussels were collected from the ropes or the floating devices (Farms $1 \& 4$ ) and at reference stations in the tidal zone approximately $500 \mathrm{~m}$ away. All samples were kept on ice during transport to the laboratory. Samples of fish intestines and blue mussels used for determination of antibacterial activity were prepared for analysis on the day of sampling. In order to choose faecal samples with antimicrobial effect on Escherichia coli $\mathrm{B}_{6}\left(E\right.$. coli $\left.\mathrm{B}_{6}\right)$ for quantitative determination of the OXA- and OTCresistant bacteria in the samples, these were prepared for analysis 2 d after sampling. Muscle samples for residue determinations were stored at $-20^{\circ} \mathrm{C}$ until analysed.

Laboratory experiments. Two laboratory experiments were carried out to investigate the absorption and excretion of OXA in saithe. In the first experiment, 154 fish weighing 270 to $850 \mathrm{~g}$ were anaesthetized with metamidat and $120 \mathrm{mg} \mathrm{kg}^{-1}$ body weight of OXA was orally administered using a stomach tube. The medicine was embedded in gelatine capsules. Muscle samples were collected from 5 fish after 10 and 23 h and $2,4,7,11,16$ and $21 \mathrm{~d}$ following medication. In the second experiment, 4 groups of 5 fish were anaesthetized with metamidat and, using a stomach tube, given $1,2,5$ and 10 medicated pellets respectively. The weight of the fish was 600 to $900 \mathrm{~g}$. Muscle samples were collected after $24 \mathrm{~h}$ and stored at $-20^{\circ} \mathrm{C}$ until analysed.

Analysis. Tissue samples were prepared for highperformance liquid chromatography (HPLC) analysis

Table 1. Specifications of the farms. C: coast; F: fjord; OXA: oxolinic acid; FLU: flumequine

\begin{tabular}{|cccccc|}
\hline Farm no. & Location & $\begin{array}{c}\text { Temp. } \\
\left({ }^{\circ} \mathrm{C}\right)\end{array}$ & $\begin{array}{c}\text { Medicated fish } \\
\text { (tonnes) }\end{array}$ & $\begin{array}{c}\text { Antibacterial } \\
\text { agent }\end{array}$ & $\begin{array}{c}\text { Amount } \\
(\mathrm{kg})\end{array}$ \\
\hline 1 & $\mathrm{C}$ & 9 & 134 & OXA & 34 \\
2 & $\mathrm{C}$ & 11 & 18 & OXA & 10 \\
3 & $\mathrm{C}$ & 14 & 70 & OXA & 26 \\
4 & $\mathrm{C}$ & 11 & 67 & OXA & 20 \\
5 & F & 10 & 51 & OXA & 1.4 \\
6 & C & 8 & FLU & 6 \\
\hline
\end{tabular}


following the procedure of Samuelsen et al. (1992). To determine the residue of OXA in tissue, FLU was used as an internal standard and vice versa, since these 2 compounds possess similar physicochemical properties but differ slightly in their chromatographic properties and thus appear at different retention times in the chromatogram. To analyse the tissue samples, the HPLC equipment and chromatographic assay described by Samuelsen (1990) were used.

The presence of antibacterial agents in the gut content of fish was examined using a standard microbiological method. Aliquots of gut contents $(0.1 \mathrm{ml})$ were applied on a thin lawn of an OXA-sensitive bacterium (E. coll $\mathrm{B}_{6}$ ) on tryptone soya agar (TSA; $20 \mathrm{~g}$ tryptone soya broth, $15 \mathrm{~g}$ Difco bacto agar, distilled water to $1 \mathrm{l}$; Oxoid Ltd., London). This test system has been proven as giving inhibition zones of $10 \mathrm{~mm}$ applying standard disks containing $2 \mu \mathrm{g}$ OXA. Since $E$. coli is an intestinal bacterium it is not inhibited by substances found in faecal material, and is thus suitable for such examinations. No inhibition zones were formed applying faecal material from drug-free control fish using this test system. The plates were incubated for $24 \mathrm{~h}$ at $37^{\circ} \mathrm{C}$. Inhibition of bacterial growth showed the presence of antibacterial substances in the sample material, which we considered as an indication for the occurrence of OXA

To examine the proportion of bacteria resistant to OXA and OTC in the soft tissue of blue mussels and in the intestinal content of fish, homogenates of blue mussels and fish faeces were plated on agar plates containing $10 \mu \mathrm{g} \mathrm{ml}^{-1}$ of OXA or $100 \mu \mathrm{g} \mathrm{ml}^{-1}$ OTC. The medium used was TSA prepared with $70 \%$ seawater (Lunestad \& Goksøyr 1990). Following 3 to 5 d of aerobic incubation at $15^{\circ} \mathrm{C}$, the number of colony-forming bacteria was compared to the number of bacteria growing on TSA without OXA or OTC. Homogenates were made of 5 to 10 blue mussels $(10 \mathrm{~g})$ or $1 \mathrm{~g}$ fish faeces, diluted 1:10 in 70\% seawater and homogenised at low speed for $1 \mathrm{~min}$.

\section{RESULTS AND DISCUSSION}

\section{Accumulations of drugs in fish}

Accumulations of drugs in wild fish were found in all fish species examined, both pelagic and demersal. The relative frequency of positive samples varied from $72 \%$ at Farm 4 to $100 \%$ at Farms $1 \& 2$, giving a mean frequency of $84 \%$ (Table 2). The mean concentration at the farms varied between $4.89 \mu \mathrm{g} \mathrm{g}^{-1}$ at Farm 1 to $0.58 \mu \mathrm{g} \mathrm{g}^{-1}$ at Farm 2, the mean concentration of all samples being $2.03 \mu \mathrm{g} \mathrm{g}^{-1}$. The high- est concentrations were found in saithe, which was also the dominant species at 5 of the farms (Table 2). For the other species the number of investigated individuals was low, but the results showed the same pattern with high relative abundance. The variance in muscle OXA concentrations among individuals was considerable (Fig. 1). Twenty-five percent of the saithe had muscle concentrations below $0.08 \mu \mathrm{g} \mathrm{g}^{-1}, 50 \%$ were below $0.48 \mu_{\mathrm{g} \mathrm{g}^{-1}}$ while $25 \%$ had concentrations exceeding $4.10 \mathrm{\mu g} \mathrm{g}^{-1}$ The highest concentration found was $15.74 \mu \mathrm{g} \mathrm{g}^{-1}$. The length of the examined saithe varied between 25 and $55 \mathrm{~cm}$ corresponding to 1 to $4 \mathrm{yr}$ of age. As we expected, no significant correlation between length and residues was found. At all the 3 farms using $20 \mathrm{~kg}$ or less of OXA or FLU, the mean concentration in muscle of saithe was approximately $1 \mu \mathrm{g} \mathrm{g}^{-1}$. When higher quantities of OXA was used, the mean residue level increased markedly (Table 2). Of 24 muscle samples from wild fish collected at Farm 4, $2 \mathrm{~d}$ prior to medication (15 saithe, 6 salmon, 3 haddock), 20 samples contained no residues of OXA or FLU while the 4 positive samples (saithe) had muscle concentrations of OXA ranging from 0.05 to $0.22 \mu \mathrm{g}$ $\mathrm{g}^{-1}$ (mean $0.12 \mu \mathrm{g} \mathrm{g}^{-1}$ ). This corresponds to a frequency of positive samples of $17 \%$.

In the laboratory experiments a maximum muscle concentration of $9.3 \mu \mathrm{gg}$ ' was obtained $47 \mathrm{~h}$ following medication, corresponding to $59 \%$ of the highest measurement in wild fish. The long absorption period might be due to slow digestion of the gelatine capsules in which the OXA was embedded. Having once reached a maximum, the concentrations decreased exponentially. After $21 \mathrm{~d}$, when terminating the experiment, the mean muscle concentration was $0.36 \mu \mathrm{g} \mathrm{g}^{-1}$ OXA (Fig. 2). After $24 \mathrm{~h}$, saithe fed 1 medicated pellet reached a mean muscle concentration of approximately $1 \mu \mathrm{g} \mathrm{g}^{-1}$, while the concentration in fish fed 10

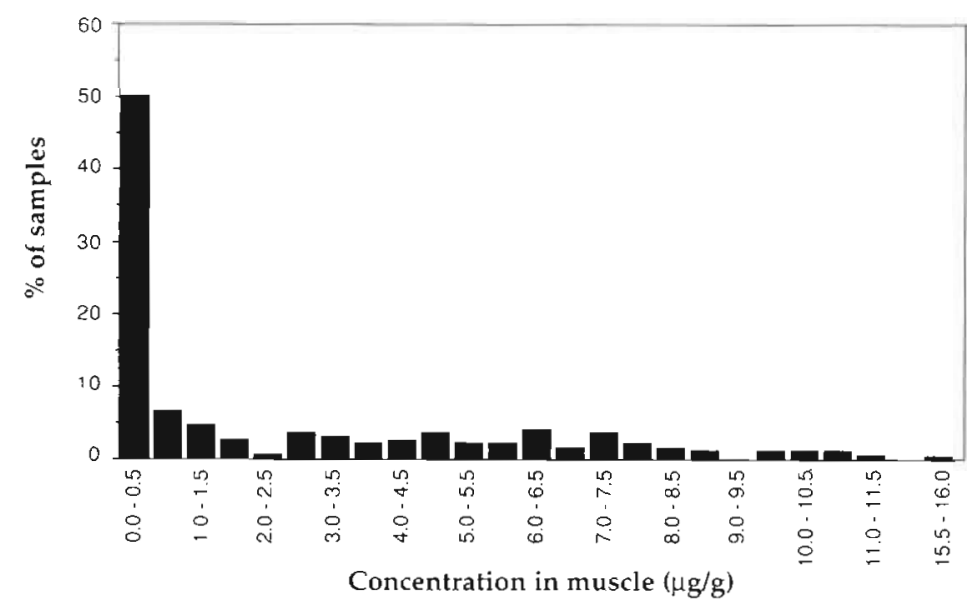

Fig. 1. Pollachius virens. Percent distribution of OXA and FLU muscle concentrations among saithe 
Table 2. Muscle residues of antibacterial agents in wild fish caught in the vicinity of fish farms after terminated medication. $\%$ Pos: : percentage containing muscle residues. Ballan wrasse $=$ Labrus bergylta, cod = Gadus morhua, flounder $=$ Platichthys flesus, haddock = Melanogrammus aeglefinus, ling = Molva molva, mackerel = Scomber scombrus, pollack = Pollachius pollachius, saithe $=$ Pollachius virens, salmon $=$ Salmo salar, whiting $=$ Merlangius merlangus. Abbreviations as in Table 1

\begin{tabular}{|c|c|c|c|c|c|}
\hline Farm no. & $\begin{array}{c}\text { Antibacterial } \\
\text { agent }\end{array}$ & Species & $\begin{array}{l}\text { Number of } \\
\text { individuals }\end{array}$ & $\%$ Pos. & $\begin{array}{l}\text { Mean muscle } \\
\text { conc. (ppm) }\end{array}$ \\
\hline \multirow[t]{6}{*}{1} & OXA & Saithe & 26 & 100 & 5.56 \\
\hline & & Ballan wrasse & 2 & 100 & 0.49 \\
\hline & & Pollack & 1 & 100 & 0.62 \\
\hline & & Haddock & 2 & 100 & 5.02 \\
\hline & & Ling & 1 & 100 & 0.20 \\
\hline & & Total & 32 & 100 & 4.89 \\
\hline \multirow[t]{4}{*}{2} & OXA & Saithe & 4 & 100 & 1.04 \\
\hline & & Mackerel & 9 & 100 & 0.37 \\
\hline & & Whiting & 2 & 0 & $<0.01$ \\
\hline & & Total & 15 & 87 & 0.58 \\
\hline \multirow[t]{5}{*}{3} & $O X A$ & Saithe & 30 & 93 & 3.21 \\
\hline & & Pollack & 7 & 86 & 0.59 \\
\hline & & Flounder & 1 & 0 & 0 \\
\hline & & Cod & 4 & 75 & 0.18 \\
\hline & & Total & 42 & 88 & 2.41 \\
\hline \multirow[t]{5}{*}{4} & OXA & Saithe & 30 & 70 & 1.08 \\
\hline & & Whiting & 4 & 100 & 1.52 \\
\hline & & Pollack & 3 & 33 & 0.04 \\
\hline & & Salmon & 2 & 72 & 0.05 \\
\hline & & Total & 39 & 72 & 1.00 \\
\hline 5 & OXA & Saithe & 30 & 77 & 1.02 \\
\hline \multirow[t]{4}{*}{6} & FLU & Saithe & 26 & 77 & 1.12 \\
\hline & & Cod & 4 & 100 & 0.06 \\
\hline & & Ling & 1 & 0 & 0 \\
\hline & & Total & 31 & 77 & 0.95 \\
\hline Total & & All & 189 & 84 & 2.03 \\
\hline
\end{tabular}

pellets was approximately $5.5 \mu \mathrm{g} \mathrm{g}^{-1}$ (Fig. 3). The calculated bioavailability of OXA in muscle of saithe tended to decrease with increasing dose, reaching 29 , 23,27 and $15 \%$ for $1,2,5$ and 10 pellets respectively. This might be explained by high stomach filling and concomitant slower absorption of OXA in the fish fed 10 pellets.

In the field investigation, a total of 189 fish representing 9 different species were analysed. Of these, 159 individuals representing 8 species contained residues of OXA or FLU. These results are in accordance with earlier findings and confirm that immediately after terminating medication a Iarge portion of the wild fish contain residues of the antibacterial agent used. In most cases the residues are low but some fish contain high concentrations. In a similar investigation in the Baltic Sea, Bjørklund et al. (1991) reported that no detectable residues of OXA were found in 25 muscle samples of bleak caught near a fish farm at the day of terminating medication. During medication a total of
$0.2 \mathrm{~kg}$ of OXA was used. In our investigation much higher quantities of antibacterial agents were applied (Table 1). As the mean residues seem to increase with increasing amount of medicine used, this may partly explain the diverging results. The species in question also have different feeding strategies. Bleak are specialized to feed on small organisms like zooplankton and insects, while most of the species we investigated are opportunistic predators adapted to particles far above pellet size. This is particularly true for saithe which is reported to school at fish farms to feed on waste food (Carss 1990, Bjordal \& Skaar 1992).

The drug residues varied greatly between the species (Table 2) and also between individual saithe, the only species sampled in relatively large numbers (Fig. 1). This variation was expected due to random sampling in an area where fish roam freely. The saithe may also belong to groups with different behavioral patterns. As demonstrated by Bjordal \& Johnstone (1993) the saithe at fish farms may consist of groups 


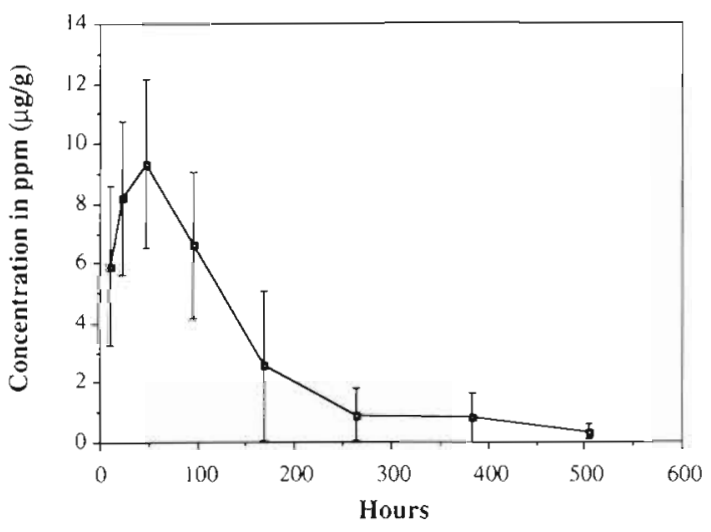

Fig. 2. Pollachius virens. Absorption and excretion of OXA in muscle of saithe. The value is the mean value of 8 samples. Vertical bars: standard deviation

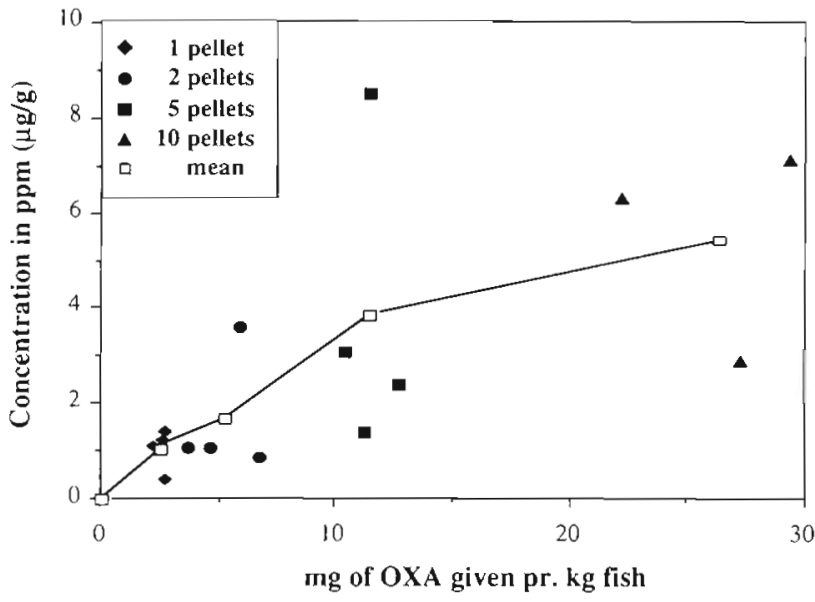

Fig. 3. Pollachius virens. OXA muscle concentration in saithe fed $1,2,5$ and 10 medicated pellets

with different core areas and varying lengths of stay at the farms. No connection was found between saithe length and drug residues, indicating that all groups feed on pellets. The fish typically varied between 25 and $55 \mathrm{~cm}$ in length, corresponding to 1 to $4 \mathrm{yr}$ of age. The majority of the fish were 2 or 3 yr old (Bjordal \& Skaar 1992). Considering that the fish retain their normal migration patterns and the slow excretion of low residue OXA, there is certainly a risk that contaminated saithe could reach human consumers. In laboratory experiments the saithe showed muscle concentrations of approximately $1 \mu \mathrm{g} \mathrm{g}^{-1}$ OXA when fed 1 medicated pellet (Fig. 3). Compared to this value the residues in wild saithe were low, with $50 \%$ of the specimens below $0.5 \mu^{-1} \mathrm{~g}^{-1}$ (Fig. 1). This indicates that for most of the wild fish population, waste feed is not a large part of the diet. However, for a small part of the population waste pellets furnish a large part of the diet. In fish, the absorption of OXA is low compared to the digestibility of the feed. Therefore, in faeces the concentration of OXA is very high compared to the concentration in the initial pellets $(O$. B. Samuelsen unpubl. results). The low residues in the majority of the saithe population therefore indicate that they do not eat faeces. This view is supported by video observations (J. E. Fosseidengen pers. comm.).

Public concern about eating fish contaminated with drugs centres mainly on toxic effects. However, development of resistant bacteria in the gut, allergic reactions, bioaccumulation and drug sensitization are possibly greater problems than toxicity.

Except for the ability of OTC to be incorporated into calcium-rich structures like bone, teeth and shell, probably none of the antibacterial agents used in Norwegian aquaculture today will bioaccumulate in the exposed organisms (Sande \& Mandell 1985). This assumption is based on the data available on the water solubility and the $n$-octanol/water partition coefficient of the different antibacterial agents (Budavari 1989). The n-octanol/water distribution of a compound is widely used as an indicator for possible bioaccumulation (Erikson et al. 1987).

\section{Occurrence of drug-resistant bacteria}

Blue mussels collected at Farm 1 had a 7 -fold increased level of OXA-resistant bacteria compared to blue mussels from the reference station $500 \mathrm{~m}$ away (from $0.015 \%$ to $0.129 \%$ ). At Farm 4, the level of OXAresistant bacteria was more than 12 -fold higher in mussels collected at the farm (10\%) compared to mussels collected in the littoral zone $500 \mathrm{~m}$ from the farm $(0.81 \%)$ and samples collected at the farm prior to medication (0.69\%). Prior to medication at Farm 4, 0.6 and $1.0 \%$ of the faecal bacteria in wild fish were resistant to OTC and OXA respectively. After terminating medication with OXA, $46 \%$ of the faecal bacteria were resistant to OXA and $20 \%$ were resistant to OTC. No antibacterial activity was found in faeces from 13 fish caught at Farm 4 prior to medication, whereas after medication an average of $60 \%$ of the samples showed antibacterial activity

This study has confirmed that the level of resistant bacteria in blue mussels and in the gut content of wild fish is affected during antimicrobial treatment of farmed fish. As previously shown by Samuelsen et al. (1992), the fraction of resistant bacteria associated with soft parts of blue mussels found near fish farm facilities increases during therapy. The development of resistant bacteria subsequently found in filter feeders may in part take place in the intestine of the fish under treatment, in the intestine of wild fish receiving drugs or in the filter feeder itself. The conditions for resistance de- 
velopment in the fish gut are favored by the high number of bacteria autochthonously present (Cahill 1990, Onarheim \& Raa 1990) combined with high concentrations of the drug being used. Of special concern in this respect is the development of coresistance between OTC and OXA (Gutman et al. 1985, Barnes et al. 1990. Hansen et al. 1993). The development of coresistance when selecting with quinolones has previously been described for a number of structurally unrelated agents such as chloramphenicol, tetracyclines, $\beta$-lactams and trimethoprim (Sanders et al. 1984, Gutman et al. 1985, Barnes et al. 1990). The mechanism involved in this kind of resistance is conferred by an alteration in outer-membrane proteins which constitutes pores through which quinolones or other antibacterial agents

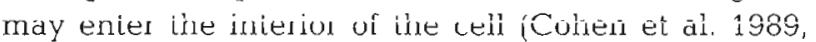
Smith 1990). In a study by Austin \& Al-Zahrani (1988) the effects of OTC, OXA and sulfafurazole on the intestinal flora of rainbow trout Oncorhynchus mykiss were discussed. The bacterial flora of the treated fish comprised a different range of taxa compared to that of untreated fish. Furthermore, bacteria in treated fish were generally resistant to the drugs in use. On the other hand, Sugita et al. (1989) reported that oral administration of OTC in a dose of $50 \mathrm{mg} \mathrm{kg}^{-1}$ fish or OXA in a dose of $20 \mathrm{mg} \mathrm{kg}^{-1}$ fish for $7 \mathrm{~d}$ did not affect the bacterial flora of goldfish Carassius auratus with respect to viable counts, generic composition and number of OXA-resistant bacteria. Our study shows an increase in resistant bacteria in the intestine of fish receiving antimicrobial drugs. The importance of horizontal gene transfer in natural environments has been emphasized (Coughter \& Stewart 1989, Anderson 1990, Levy 1990, Stewart \& Sinigalliano 1990). In this respect special concern has been given to the possibility for transfer of resistance genes from bacteria in the environment to bacteria pathogenic to fish or humans (Nakajima et al. 1983, Husevåg et al. 1991). In fact, conjugal transfer of resistance plasmids from Vibrio anguillarum to Escherichia colj and from $V$. anguillarum to $V$. cholerae has been demonstrated showing that this is not only a hypothetical problem (Nakajima et al. 1983. Sandaa et al. 1993). Since resistance towards OXA has not been shown to be plasmid mediated (Courvalin 1990), the implications of drug use in aquaculture on the overall quinolone resistance problem are currently unknown. Successful fish farming is dependent on a good environment. It is therefore in the interest of the fish farmer to reduce the usage of drugs in aquaculture. Although fragmentary, our present knowledge calls for a most prudent use of these drugs. The problems associated with bacterial diseases in farmed fish cannot be solved by an increasing use of antibacterial agents. Instead, further work should be done on improving the general health condi- tions of cultured organisms, including the development of effective vaccines.

Acknowledgements. The technical assistance of Ms El. Tepstad, Ms Laila Unneland and Mr Audun Hoylandsskjær is highly appreciated. We thank the owners and workers at the salmon farms for valuable information and help during sampling. We also thank Prof. R. R. Scheline for critical comments on the manuscript. This investigation was supported financially by the Norwegian Department for Fisheries and the Norwegian Research Council for Fisheries Science.

\section{LITERATURE CITED}

Anderson, S. (1990). Transfer of antibiotic resistance among waste-water bacteria. In: European Environmental Research Organization workshop on molecular microbial ecology, Königslutter, April 28-May 1. Gesellschaft für Biotechnologische Forschung, Braunschweig (Abstract)

Austin, B., Al-Zahrani, A. M. J. (1988). The effect of antimicrobial compounds on the gastrointestinal microflora of rainbow trout, Salmo gairdnerj Richardson. J. Fish Biol. 33 $1-14$

Barnes, A. C., Lewin, C. S., Hastings, T S., Amyes, S. G. B (1990). Cross resistance between oxytetracycline and oxulinic acid in Aeromonas salmonicida associated with alteration in outer membrane proteins. FEMS Lett. 72 $337-340$

Bjordal, A., Johnstone, A. D. F. (1993). Local movement of saithe (Polachius virens L.) in the vicinity of fish farm cages. Mar Sci. Symp. int. Counc. Explor. Sea 196: $1.43-146$

Bjordal, A., Skaar, A. B. (1992). Tagging of saithe (Polachius virens L.) at a Norwegian fish farm: preliminary results on migration. Comm. Meet. int. Coun. Explor Sea C.M. ICES/G: 35

Björklund, H., Bondestam, J., Bylund, G. (1990). Residues of oxytetracycline in wild fish and sediments from fish farms. Aquaculture 86: 359-367

Björklund, H., Bylund, G. (1991). Comparative pharmacokinetics and bioavailability of oxolinic acid and oxytetracycline in rainbow trout (Oncorhynchus mykiss). Xenobiotica 21: 1511-1520

Björklund, H., Råbergh, C. M. I., Bylund, G. (1991). Residues of oxolinic acid and oxytetracycline in fish and sediments from fish farms. Aquaculture 97: 85-96

Budavari, S. (ed.) (1989). Merck: index of chemicals, drugs and biologicals. Merck \& Co., Rahway, NJ

Cahill, M. M. (1990). Bacterial flora of fishes: a review. Microb. Ecol. 19: 21-41

Carss, D. N. (1990). Concentrations of wild fish and escaped fishes immediately adjacent to fish farm cages. Aquaculture 90: $29-40$

Cohen, S. P., McMurry, L. M., Hooper, D. C., Wolfson, J. S., Levy, S. B. (1989). Cross-resistance to fluoroquinolones in multiple-antibiotic-resistant (Mar) Escherichia coli selected by tetracycline or chloramphenicol: decreased drug accumulation associaled with membrane changes in addition to OmpF reduction. Antimicrob. Agents Chemother. 33: $1318-1325$

Coughter, J. P., Stewart, G. J. (1989). Mini review: genetic exchange in the environment. Antonie van Leeuwenhoek 55: $15-22$

Courvalin, P. (1990). Minireview: plasmid-mediated 4-quino- 
lone resistance: a real or apparent absence? Antimicrob. Agents Chemother. 34:681-684

Erikson, C., Harrass, M. C., Osborne, C. M., Sayre, P. G., Zeeman, M. (1987). Environmental assessment technical handbook. U.S. Food and Drug Administration, Center for Food Safety and Applied Nutrition and Center for Veterinary Medicine

Gutman, L., Williamson, R., Moreau, N., Kitzis, M. D., Collatz, E., Acar, J. F., Goldstein, A. C. (1985). Cross-resistance to nalidixic acid, trimethoprim and chloramphenicol associated with alterations in outer membrane proteins of Klebsiella, Enterobacter and Serratia. J infect. Dis. 151 501-507

Hansen, P. K., Lunestad, B. T., Samuelsen, O. B. (1993). Effects of oxytetracycline, oxolinic acid and flumequine on bacteria in an artificial marine fish farm sediment. Can. J. Microbiol. 38: 1307-1312

Higuera, I. C., Brown, J. H., Jauncey, K. (1990). Leaching of oxytetracycline from pelleted shrimp feed. Abstract from the conference: Bacterial diseases of fish, University of Stirling, Scotland, UK, June 26-29. Univ. of Stirling Press, Stirling

Husevåg, B., Lunestad, B. T., Johannessen, P. J., Enger, $\varnothing$., Samuelsen, O. B. (1991). Simultaneous occurrence of Vibrio salmonicida and antibiotic-resistant bacteria in sediments at abandoned aquaculture sites. J. Fish Dis. 14: $631-640$

Hustvedt, S. O., Salte, R., Kvendseth, O., Vassvik, V. (1991). Bioavailability of oxolinic acid in Atlantic salmon (Salmo salar L.) from medicated feed. Aquaculture 97: 305-310

Levy, S. B. (1990). Spread of antibiotic resistance genes in the natural environment. In: European Environmental Research Organization workshop on molecular microbial ecology, Königslutter, April 28-May 1. Gesellschaft für Biotechnologische Forschung. Braunschweig (A.bstract)

Lunestad, B. T., Goksøyr, J. (1990). Reduction in the antibacterial effect of oxytetracycline in sea water by complex formation with magnesium and calcium. Dis. aquat. Org. 9: $67-72$

Møster, G. (1986). Bruk av antibiotika i fiskeoppdrett. (Use of antibiotics in Norweglan aquaculture). Sogn og Fjordane Distriktshøgskule, Sogndal (in Norwegian)

Responsible Subject Editor: O. Kinne, Oldendorf/Luhe, Germany
Nakajima, T., Suzuki, M., Harada, K., Inoue, M., Mitsuhashi, $\mathrm{S}$. (1983). Transmission of $\mathrm{R}$ plasmids in Vibrio anguillarum to Vibrio cholerae. Microbiol. Immunol. 27: 195-198

Onarheim, A. M., Raa, J. (1990). Characteristics and possible biological significance of an autochtonous flora in the intestinal mucosa of sea-water fish. In: Lésel, R. (ed.) Microbiology in poikilotherms. Elsevier, Amsterdam

Samuelsen, O. B. (1990). Simple and rapid determination of flumequine and oxolinic acid in salmon (Salmo salar) plasma by high-performance liquid chromatography and fluorescence detection. J. Chromatogr. 530: 452-457

Samuelsen, O. B., Lunestad, B. T., Husevåg, B., Holleland, T., Ervik, A. (1992). Residues of oxolinic acid in wild fauna following medication in fish farms. Dis. aquat. Org. 12 : $111-119$

Sandaa, R.-A., Torsvik, V. L., Goksoyr, J. (1993). Transferable drug resistance in bacteria from fish-farm sediments. Can. J. Microbiol. 38: 1061-1065

Sande, M. A., Mandell, G. L. (1985). Antimicrobial agents: tetracyclines, chloramphenicol, erythromycin and miscellaneous antibacterial agents. In: Goodman, L. S., Gilman, A., Rall, T. W., Murad, F. (eds.) Goodman and Gillman's the pharmacological basis of therapeutics, 7 th edn. Macmillan, New York, p. 1170-1198

Sanders, C. C., Sanders, W. E., Goering, R. V., Werner, V. (1984). Selection of multiple antibiotic resistance by quinolones, $\beta$-lactams and aminoglycosides with special reference to cross-resistance between unrelated drug classes. Antimicrob. Agents Chemother. 26: $797-801$

Smith, J T. (1990). In vitro and in vivo mutation frequencies to resistance - do they correlate in the long term? In: Crumplin, G. C. (ed.) The 4-quinolones: antibacterial agents in vitro. Springer-Verlag, London, p. 215-227

Stewart, G. J., Sinigalliano, C. D. (1990). Detection of horizontal gene transfer by natural transformation in native and introduced species of bacteria in marine and synthetic sediments. Appl environ. Microbiol. 56: 1818-1824

Sugita, H., Miyajima, C., Fukumoto, M., Koyama, H. Deguchi, Y (1989). Effects of oxolinic acid on fecal microflora of goldfish (Carassius auratus). Aquaculture 80: $163-174$

Manuscript first received: June 18, 1993

Revised version accepted: October 19, 1993 